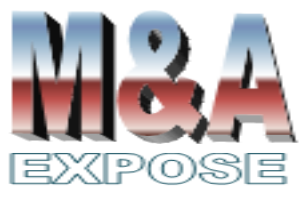

http://jurnal.usahid.ac.id/index .php/accounting
${ }^{1}$ Politeknik Kesehatan Kemenkes Semarang dewiermawati@gmail.com

${ }^{2}$ Sekolah Tinggi IImu Ekonomi Bank BPD Jateng fitri111269@stiebankbpdiaten g.ac.id

\section{Determinan Perilaku Kunjungan Lansia Ke Posyandu Dengan Dukungan Keluarga Sebagai Variabel Moderasi}

\author{
Dewi Ermawati ${ }^{1}$, Fitri Lukiastuti ${ }^{2}$
}

\section{Abstrak}

Penelitian ini bertujuan untuk menganalisis faktor-faktor yang mempengaruhi perilaku kunjungan lansia, serta dukungan keluarga dalam memoderasi faktor-faktor yang mempengaruhi perilaku kunjungan lansia ke Posyandu Lansia. Metode pengumpulan data yang digunakan yaitu metode survei yang dilaksanakan di Desa Gejagan Kecamatan Ngadirejo Kabupaten Temanggung. Tehnik sampling menggunakan total sampling. Tehnik analisis data menggunakan Moderated Regression Analysis (MRA). Hasil penelitian menyimpulkan bahwa pengetahuan, sikap dan dukungan masyarakat berpengaruh positif signifikan terhadap perilaku kunjungan lansia ke Posyandu Lansia. Adapun akses dan pekerjaan tidak berpengaruh signifikan terhadap perilaku kunjungan lansia ke Posyandu Lansia. Dukungan keluarga terbukti mampu memoderasi faktor-faktor yang mempengaruhi perilaku kunjungan lansia.

Kata kunci : perilaku kunjungan lansia, Posyandu Lansia, dukungan keluarga

\section{Abstract}

This study aims to analyze the factors that influence the behavior of elderly visits, as well as family support in moderating the factors that influence the behavior of elderly visits to Posyandu Seniors. Data collection methods used were survey methods carried out in Gejagan Village, Ngadirejo District, Temanggung Regency. The sampling technique uses total sampling. Data analysis techniques use Moderated Regression Analysis (MRA). The results of the study concluded that community knowledge, attitudes and support had a significant positive effect on the behavior of elderly visits to Posyandu Seniors. The access and employment does not significantly influence the behavior of elderly visits to the Posyandu Elderly. Family support is proven to be able to moderate the factors that influence the behavior of elderly visits.

Keywords: elderly visiting behavior, Elderly Posyandu, family support 


\section{PENDAHULUAN}

Pemerintah mencanangkan pelayanan untuk lansia melalui beberapa tahapan. Pelayanan tersebut yaitu Pos Pelayanan Terpadu Lanjut Usia (Posyandu Lansia) yang merupakan pelayanan pada tingkat masyarakat sehingga pelayanan yang diberikan lebih dekat atau terjangkau dan mampu dimanfaatkan oleh masyarakat setempat (Erfandi, 2013).

Posyandu Lansia yang berada di Desa Gejagan, Kecamatan Ngadirejo, Kabupaten Temanggung merupakan tempat terpadu yang ditujukan untuk lansia agar lebih diperhatikan dalam masyarakat. Hasil observasi sementara adalah masih terdapat lansia yang frekuensi kunjungannya ke Posyandu Lansia belum sesuai harapan. Dari 118 lansia di desa tersebut, hanya 60 lansia (51 persen) yang aktif mengikuti kegiatan di Posyandu Lansia. Hal ini dipengaruhi beberapa faktor, di antaranya pengetahuan lansia, serta keluarga yang kurang mendukung dalam menemani atau mengingatkan agar datang ke posyandu.

Posyandu lansia adalah pos pelayanan terpadu untuk masyarakat lanjut usia yang sudah disepakati, yang digerakkan oleh masyarakat di mana mereka bisa mendapatkan pelayanan kesehatan (Sulistyorini, 2010). Di samping itu, Posyandu Lansia juga memberikan pelayanan sosial, agama, keterampilan, olahraga dan seni budaya serta pelayanan lain yang dibutuhkan para lanjut usia dalam rangka meningkatkan kualitas hidup melalui peningkatan kesehatan dan kesejahteraan mereka. Selain itu, Posyandu Lansia juga menjadi wadah mereka beraktifitas dan mengembangkan potensi diri (Soeweno, 2010).

Perilaku dipengaruhi oleh faktor pengetahuan, kepercayaan dan sikap positif, tersedianya sarana dan prasarana yang diperlukan dan terdapat dorongan yang dilandasi kebutuhan yang dirasakan. Sikap lanjut usia perempuan dan laki-laki dapat berupa sikap positif (mendukung) dan sikap negatif (menolak). Terdapat tiga faktor yang saling menunjang untuk pembentukan sikap, yaitu kognitif, konatif, dan afektif yang merupakan presdiposisi terhadap tindakan dan perilaku seseorang (Arwani, 2015).

Pengetahuan lansia menjadi faktor yang dapat mempengaruhi peningkatan motivasi lansia dalam mengunjungi pelayanan posyandu lansia. Menurut Notoatmodjo (2010) bahwa tindakan seseorang individu termasuk kemandirian dan tanggung jawabnya dalam berperilaku digerakkan domain kognitif atau pengetahuan.

Perilaku individu akan lebih langgeng dan bertahan lama apabila didasari oleh pengetahuan yang baik. Lansia yang mempunyai pengetahuan tinggi akan termotivasi dalam mendatangi Posyandu Lansia. Alhidayati (2014) menunjukkan bahwa pengetahuan lansia mengenai posyandu lansia berpengaruh signifikan terhadap perilakunya dalam berkunjung. Selain pengetahuan lansia, dukungan masyarakat, sikap, akses dan pekerjaan lansia juga mejadi faktor yang mempengaruhi lansia untuk berkunjung ke Posyandu Lansia. Jika dilihat dari aksesnya, jarak posyandu yang dekat akan membuat lansia mudah menjangkau posyandu tanpa harus mengalami kelelahan fisik karena penurunan daya tahan atau kekuatan fisik tubuh. Kemudahan dalam menjangkau lokasi posyandu juga membuat lansia merasa aman sehingga mendorong minat lansia untuk mengikuti posyandu (Sulistyorini, 2010).

Dari segi dukungan masyarakat dan pekerjaannya, dukungan sosial dari masyarakat sekitar akan mempengaruhi seseorang berperilaku terhadap kesehatan. Apabila perilaku tersebut tidak memperoleh dukungan dari masyarakat, maka seseorang akan merasa tidak nyaman sehingga tidak mempunyai motivasi untuk melakukan perilaku kesehatan (Notoatmodjo, 2010). 
Sunartyasih (2011) menyatakan bahwa dukungan keluarga berhubungan erat dengan kunjungan lansia ke posyandu. Menurut Puspitawati (2012) dan Gestinarwati, dkk (2016) bahwa keluarga berfungsi sebagai sistem pendukung bagi anggotanya. Dukungan tersebut dapat dilakukan dengan cara meningkatkan dukungan emosional, penghargaan, instrumental, dan informatif yang diberikan oleh anggota keluarganya. Oleh sebab itu, peran keluarga menjadi bagian terpenting dalam rangka perawatan kesehatan serta kesejahteraan lanjut usia. Dukungan tersebut akan memotivasi juga pada diri seorang lansia untuk datang dan berpartisipasi dalam program lansia.

Berdasarkan identifikasi masalah tersebut, maka menarik untuk menganalisis kunjungan lansia dengan fokus peran dukungan keluarga dalam memperkuat faktor-faktor yang mempengaruhi perilaku kunjungan lansia ke Posyandu Lansia.

\section{TINJAUAN PUSTAKA}

Lansia merupakan seseorang yang mengalami tahap akhir dalam perkembangan kehidupan manusia. Pengertian lansia merupakan suatu proses alamiah pada manusia yang terjadi bedasarkan beberapa fase yang harus dilewati yaitu anak, dewasa, dan tua (Dewi, 2014). Susilo (2017) juga menambahkan bahwa pengertian lansia merupakan suatu proses kehidupan seseorang yang pada tahap ini banyak mengalami penurunan fisik secara biologis seperti menurunnya masa otot dan tulang yang pada akhirnya akan membuat lansia renta terhadap resiko jatuh dan juga terjadi perubahan sosial untuk berinteraksi dengan yang lainnya, psikologi, sehingga akan menyebabkan permasalahan pada keehatan fisik maupun jiwa lansia.

Departemen Kesehatan RI (2013) mengklasifikasikan lansia berdasarkan usia sebagai berikut :

1. Pra lansia,yaitu seorang yang memiliki usia diantara 45 tahun sampai dengan 59 tahun.

2. Lansia, merupakan usia seseorang yang telah menginjak angka 60 tahun lebih.

3. Lansia dengan resiko tinggi, merupakan lansia yang memiliki masalah pada kesehatannya.

4. Lansia potensial merupakan lansia yang bisa dan masih mampu atau berpotnesi untuk bekerja dan bisa mendapatkan hasil barang.

5. Lansia tidak potensial, yaitu lansia yang sudah tidak berdaya dalam mencari nafkah, sehingga dalam menyukupi hidupnya tergantung dengan bantuan orang lain.

Posyandu lansia adalah suatu fasilitas pelayanan kesehatan dengan sasarannya masyarakat lansia yang bertujuan untuk melaksanakan suatu proses pembentukan yang bersumber daya dari masyarakat, dilaksanakan oleh masyarakat bersama Lembaga Swadaya Masyarakat, lintas sektoral, non pemerintah, swasta, dan lembaga lainnya, dengan fokus pelayanannya terletak di upaya promotif dan juga preventif. Disamping itu, peningkatan kesehatan dan kesejateraan lansia diupayakan melalui beberapa pelayanan yang diberikan posyandu agar meningkatkan kualitas hidup pada lansia seperti pelayanan olah raga, agama, sosial, keterampilan, pendidikan dan beberapa pelayanan lainnya. Selain itu, Posyandu lansia mampu meningkatkan kreatifitas dan mengembangkan potensi lansia (Kemenkes, 2014). 
Tujuan umum pembentukan posyandu lansia menurut Departemen Kesehatan RI (2010) adalah meningkatkan derajat kesehatan dan mutu kehidupan lansia untuk mencapai masa tua yang bahagia dan berdaya guna dalam kehidupan keluarga dan masyarakat sesuai dengan keberadaannya. Tujuan khusus pembentukan posyandu lansia yaitu:

1. Meningkatkan kesadaran lansia untuk membina sendiri kesehatannya.

2. Meningkatkan kemampuan dan peran serta keluarga dan masyarakat dalam menghayati kesehatan lansia.

3. Meningkatkan jenis dan jangkauan pelayanan kesehatan lansia.

4. Meningkatkan mutu pelayanan kesehatan lansia.

Posyandu Lansia. Kegiatan posyandu lansia meliputi kegiatan pelayanan kesehatan dan kegiatan lain yang bertujuan meningkatkan kualitas hidup lansia. Beberapa bentuk dari pelayanannya yaitu adanya pemeriksaan kesehatan pasa fisik, emosional dan mental lansia, yang pada pemeriksaanya ini dipantau menggunakan KMS atau Kartu Menuju Sehat, yang bertujuan untuk mendeteksi dini penyakit atau ancaman kesehatatan yang diderita lansia. Kegiatan-kegiatan yang dilakasanakan Posyandu Lansia berdasarkan Depkes RI (2010) meliputi :

1. Pemeriksaan terhadap aktivitasnya setiap hari, sepertinya halnya ketika makan atau minum, berpakaian, mandi, saat berjalan, naik dan turun tempat tidur, BAB dan beberapa aktivitas lainnya.

2. Pemeriksaan status mental ini dilaksankan dengan menggunakan pedoman metode 2 menit untuk pelaksanaannya.

3. Pemeriksaan pada status gizi dengan melakukan penimbangan berat badannya lansia juga tinggi badan yang selanjutnya untuk dilakukan pengukuran indeks masa tubuh lansia.

4. Mengukur tekanan darah pada lansia serta penghitungan denyut nadinya dalam waktu 1 menit.

5. Melakukan pemeriksaan darah hemoglobin.

6. Pemeriksaan gula dengan media air seni atau urine sebagai langkah awal deteksi penyakit DM.

7. Pemeriksaan kesehatan pada ginjal dengan memeriksa zat putih telur atau protein urin Melaksanakan rujukan ke puskesmas jika ditemukan permasalah pada item-item diatas.

8. Melakukan penyuluhan kesehatan secara berkelompok atau dengan kunjungan ke rumah-rumah, melakukan konseling kesehatan serta gizi berdasarkan permasalahan yang sedang dirasakan lansia.

9. Kader melakukan kunjungan rumah yang didampingi oleh petugas bagi kelompok di usia lanjut untuk mengupayakan suatu kegiatan perawat dalam masyarakat.

10. Mengadakan kegiatan lainnya seperti pengajian, senam lansi, kegiatan silaturahim, kegiatan kerajinan dan lain sebagainya. Kegiatan ini ada sesuai dengan kreatifitas kader posyandunya agar membuat lansia mau beraktivitas dan berdisiplin lagi.

Salah satu upaya yang telah dilakukan untuk peningkatan kesehatan terutama dalam menunjang status gizi lansia dan pencegahan penyakit, dapat dilakukan terhadap pemantauan keadaan kesehatan lansia secara berkala menggunakan Kartu Menuju Sehat untuk lansia, yang harapannya dapat terdeteksi jika terdapat gangguan kesehatan lansia sehingga mendapatkan pertolongan secara cepat, tepat dan memadai sesuai dengan keinginan yang diperlukan (Depkes Rl, 2013). 
Konsep Perilaku. Skiner (1938) dalam Notoatmodjo (2012) merumuskan bahwa perilaku merupakan respon atau reaksi seseorang terhadap stimulus (rangsangan dari luar). Selanjutnya teori Skiner menjelaskan adanya dua jenis respon, yaitu:

1. Responden Respons atau Refleksi yakni respon yang ditimbulkan oleh rangsanganrangsangan tertentu yang disebut electing stimuli karena menimbulkan respon yang relative tetap.

2. Operant respon atau instrumental respons, yakni respon yang timbul dan berkembang kemudian diikuti oleh rangsangan yang lain.

Pengembangan Hipotesis. Pengetahuan yang rendah tentang manfaat Posyandu Lansia menjadi kendala dalam mengikuti Posyandu Lansia. Pengetahuan yang salah tentang tujuan dan manfaat posyandu dapat menimbulkan salah persepsi yang menurunkan minat kunjungan ke posyandu (Purnama, 2010). Hal ini didukung Alhidayati (2014) bahwa pengetahuan lansia berpengaruh signifikan terhadap perilaku kunjungan lansia. Hal ini dikuatkan Iskandar dan Sunarti (2017) bahwa pengetahuan lansia berhubungan dengan perilaku kunjungan lansia. Berdasarkan uraian tersebut, maka diajukan hipotesis berikut :

$\mathrm{H} 1$ : Terdapat pengaruh positif pengetahuan lansia terhadap perilaku kunjungan lansia.

Notoatmodjo (2010) menyatakan bahwa dukungan sosial masyarakat sekitar akan mempengaruhi perilaku seseorang terhadap kesehatan. Apabila perilaku tersebut tidak memperoleh dukungan dari masyarakat, maka seseorang akan merasa tidak nyaman sehingga tidak mempunyai motivasi untuk melakukan perilaku kesehatan. Menurut Umayana (2015) dukungan mayarakat yang kurang atau cukup memiliki peluang 1,52 kali untuk tidak aktif dalam mengikuti kegiatan posbindu daripada penduduk dengan dukungan baik dari tokoh masyarakat. Berdasarkan uraian tersebut, maka diajukan hipotesis berikut :

$\mathrm{H}_{2}$ : Terdapat pengaruh positif dukungan masyarakat terhadap perilaku kunjungan lansia

Sikap merupakan reaksi atau respons seseorang yang masih tertutup terhadap suatu stimulus atau objek, yang sudah melibatkan faktor pendapat dan emosi yang bersangkutan (Notoatmodjo, 2012). Sejalan dengan Sunartyasih (2012) bahwa sikap lansia berpengaruh terhadap kehadiran lansia ke posbindu. Notoatmodjo (2010) dan Handayani (2016), menyimpulkan bahwa ada keterkaitan hubungan antara sikap dengan pemanfaatan posyandu lansia. Berdasarkan uraian tersebut, maka diajukan hipotesis berikut :

H3 : Terdapat pengaruh positif sikap terhadap perilaku kunjungan lansia

Menurut Erfandi (2013) terdapat lima faktor kendala pelaksanaan posyandu, salah satunya akses atau jarak. Jarak posyandu yang dekat akan memudahkan lansia menjangkau posyandu tanpa harus mengalami kelelahan karena penurunan daya tahan atau kekuatan fisik. Kemudahan menjangkau lokasi posyandu berhubungan dengan faktor keamanan atau keselamatan. Jika lansia merasa aman atau mudah menjangkau lokasi posyandu, maka hal ini dapat mendorong minat atau motivasi lansia untuk mengikuti kegiatan posyandu. Hal ini senada dengan Ningsih (2014) yang menyatakan pengaruh signifikan antara akses tempat tinggal dengan minat lansia mengunjungi Posyandu Lansia. Berdasarkan uraian tersebut, maka diajukan hipotesis berikut :

$\mathrm{H} 4$ : Terdapat pengaruh positif akses terhadap perilaku kunjungan lansia

Pekerjaan adalah jenis kegiatan yang menggunakan waktu terbanyak atau yang memberikan penghasilan terbesar. Arikunto (2013) mengemukakan bahwa pekerjaan adalah aktivitas yang dilakukan seseorang setiap hari dalam kehidupan untuk memenuhi kebutuhan hidup. Lingkungan pekerjaan dapat menjadikan seseorang memperoleh 
pengalaman dan pengetahuan baik secara langsung maupun tidak lansung. Sulistyawati (2012) menunjukkan bahwa pekerjaan merupakan faktor yang mempengaruhi lansia untuk datang atau berkunjunga ke Posyandu Lansia. Purnawati, et al. (2014) menyimpulkan bahwa pekerjaan merupakan faktor yang mempengaruhi kunjungan lansia ke posyandu di mana pemanfatan posyandu yang baik lebih banyak dilakukan oleh lansia yang tidak bekerja. Menurut Andini (2013), Henniwati (2008), dan Rosyid (2009), lansia yang bekerja akan lebih sibuk sehingga tidak ada waktu untuk berkunjung ke posyandu dibanding dengan lansia yang tidak bekerja. Berdasarkan uraian tersebut, maka diajukan hipotesis berikut :

H5 : Terdapat pengaruh positif pekerjaan lansia terhadap perilaku kunjungan lansia

Menurut Puspitawati (2012) keluarga berfungsi sebagai sistem pendukung bagi anggotanya. Dukungan tersebut dapat dilakukan dengan meningkatkan dukungan emosional, penghargaan, instrumental, dan informatif oleh anggota keluarganya. Pengetahuan yang rendah tentang manfaat Posyandu Lansia dapat menjadi kendala bagi lansia dalam mengikuti kegiatan Posyandu Lansia. Pengetahuan yang salah tentang tujuan dan manfaat posyandu dapat menimbulkan salah persepsi yang menurunkan kunjungan ke posyandu (Purnama, 2010). Hal ini didukung Alhidayati (2014) dan Iskandar \& Sunarti (2017) yang menyatakan pengetahuan lansia berpengaruh signifikan terhadap perilaku kunjungan lansia. Purnawati (2014) menyatakan faktor yang mempengaruhi perilaku lansia untuk berkunjung ke Posyandu Lansia di antaranya pengetahuan, dukungan masyarakat, sikap, akses, pekerjaan, dukungan keluarga. Adapun faktor yang paling dominan yaitu dukungan keluarga. Berdasarkan uraian tersebut, maka diajukan hipotesis berikut :

H6 : Dukungan keluarga memoderasi pengetahuan lansia terhadap perilaku kunjungan lansia.

$\mathrm{H} 7$ : Dukungan keluarga memoderasi dukungan masyarakat terhadap perilaku kunjungan lansia.

H8 : Dukungan keluarga memoderasi sikap terhadap perilaku kunjungan lansia.

$\mathrm{H} 9$ : Dukungan keluarga memoderasi akses terhadap perilaku kunjungan lansia.

H10 : Dukungan keluarga memoderasi pekerjaan lansia terhadap perilaku kunjungan lansia.

Kerangka penelitian dapat diilustrasikan dalam gambar berikut :

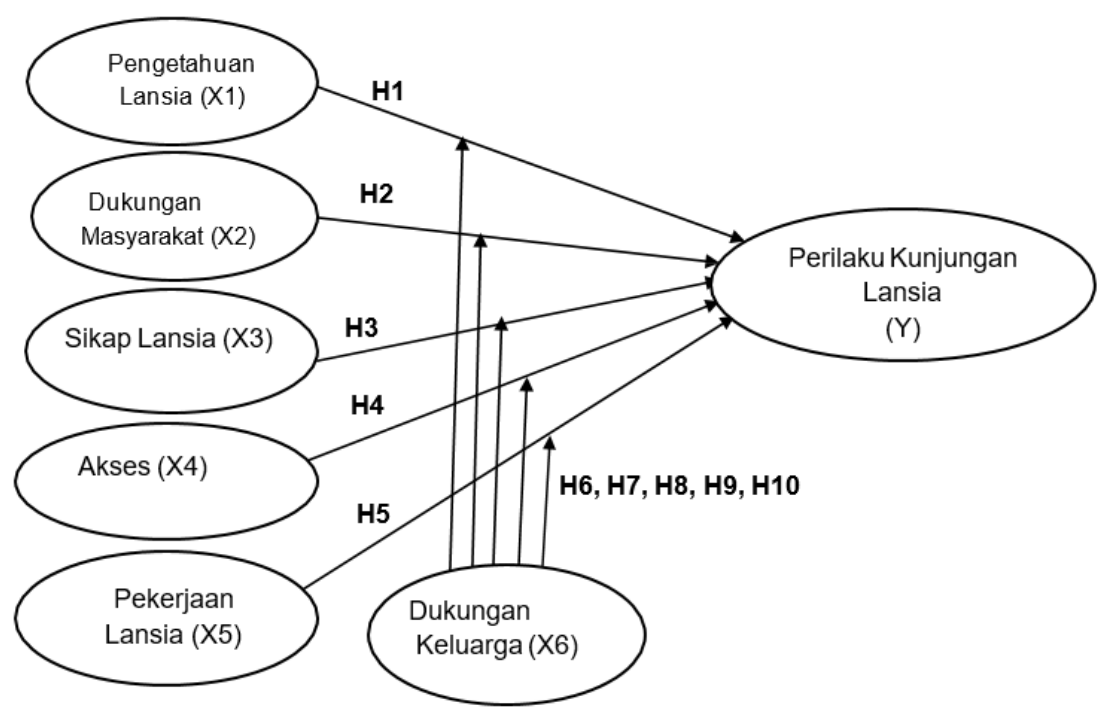

Gambar 1. Model Penelitian 


\section{METODE PENELITIAN}

Data primer diperoleh peneliti secara langsung dari hasil penyebaran kuesioner kepada lansia di wilayah kerja Puskesmas Ngadirejo mengenai pengetahuan, dukungan keluarga dan sikap lansia terhadap posyandu lansia. Populasi yang digunakan adalah semua lansia golongan A yang dapat beraktifitas sendiri di Posyandu Lansia Desa Gejagan, Kecamatan Ngadirejo Kabupaten Temanggung sejumlah 118 lansia. Seluruh anggota populasi digunakan sebagai sampel (metode sensus).

Pengetahuan lansia diukur melalui indikator yang mengacu Sumiati (2013) dan Oktaviani (2016), yaitu pengertian Posyandu Lansia, tujuan diselenggarakannya Posyandu Lansia, manfaat Posyandu Lansia, bentuk-bentuk pelayanan di Posyandu Lansia, dan sistem atau jenis kegiatan dalam pelayanan. Dukungan masyarakat diukur dengan indikator menurut Wahyuni (2017) berupa keaktifan masyarakat/kader dalam kegiatan Posyandu Lansia, masyarakat/kader memotivasi dan menyarankan lansia untuk selalu datang ke Posyandu Lansia, masyarakat/kader memberikan informasi tentang adanya kegiatan Posyandu Lansia, masyarakat/kader memberikan informasi terkait manfaat Posyandu Lansia. Sikap lansia diukur dengan indikator menurut Wahyuni (2017) yaitu persepsi lansia terhadap adanya Posyandu Lansia, persepsi kesehatan lansia, persepsi lansia dalam meningkatkan semangat dan motivasinya untuk datang ke Posyandu Lansia. Akses diukur dengan indikator menurut Utomo (2015) yaitu keterjangkauan lansia menunju ke Posyandu Lansia (jarak), biaya transportasi menuju Posyandu Lansia (rupiah). Pekerjaan lansia diukur dengan indikator berdasarkan teori As'ad (2013) yaitu jenis kegiatan/pekerjaan berat atau mudah, penghasilannya mampu memenuhi kebutuhan. Dukungan keluarga diukur dengan indikator menurut Erfandi (2013) yaitu ketersediaan anggota keluarga untuk menyediakan diri melakukan pendampingan lansia ke Posyandu Lansia, mengingatkan lansia jadwal Posyandu Lansia, usaha membantu dan mengatasi berbagai permasalan secara bersama dengan lansia. Perilaku kunjungan lansia diukur dengan indikator menurut Notoadtmodjo (2010) yaitu kognitif (peningkatan pengetahuan), afektif (tanggapan setelah mengikuti Posyandu Lansia), dan psikomotor (praktik/motivasi untuk datang kembali).

Alat analisis yang digunakan adalah moderated regression analysis (MRA). Analisis tersebut digunakan untuk melihat apakah variabel pemoderasi (XM) menguatkan atau tidak dalam pengaruh antara variabel independen terhadap variabel dependen (Ghozali, 2011). Adapun persamaan regresi yang diajukan adalah :

$Y=a_{1}+b_{1} X_{1}+b_{6} X_{6}+b_{11} X_{1} X_{6}+e_{1} ;$
$Y=a_{2}+b_{2} X_{2}+b_{7} X_{6}+b_{12} X_{2} X_{6}+e_{2}$
$Y=a_{3}+b_{3} X_{3}+b_{8} X_{6}+b_{13} X_{3} X_{6}+e_{3}$
$Y=a_{4}+b_{4} X_{4}+b_{9} X_{6}+b_{14} X_{4} X_{6}+e_{4}$
$Y=a_{5}+b_{5} X_{5}+b_{10} X_{6}+b_{15} X_{5} X_{6}+e_{5}$

\section{HASIL DAN PEMBAHASAN}

Tabel 1 mempresentasikan karakteristik demografis responden di Desa Gejagan, Temanggung. Menurut Organisasi Kesehatan Dunia (WHO) tingkat usia 60-70 tahun tergolong usia lanjut dan tingkat usia $>70$ tahun tergolong usia lanjut tua. Di Desa Gejagan 
responden yang berusia lanjut sebanyak 75,4 persen, sedangkan usia lanjut tua sebanyak 24,6 persen. Jadi responden termasuk lansia potensial yang masih mampu atau berpotensi untuk bekerja dan bisa mendapatkan penghasilan. Jenis kelamin lansia perempuan sebanyak 51,6 persen, sedangkan lansia pria sebanyak 48,3 persen. Rata-rata tingkat pendidikan mereka adalah tamat SD, serta sebagian besar pekerjaan mereka adalah petani.

Tabel 1. Demografis Responden

\begin{tabular}{lcrr}
\hline Keterangan & Indikator & Frekuensi & Persentase \\
\hline Tingkat Usia & $60-70$ & 89 & 75.4 \\
& $>70$ & 29 & 24.6 \\
\multirow{4}{*}{ Jenis Kelamin } & Total & 118 & 100.0 \\
& Laki-laki & 57 & 48.3 \\
& Perempuan & 61 & 51.6 \\
Tingkat Pendidikan & Total & 118 & 100.0 \\
& Tidak Tamat SD & 39 & 33.0 \\
& Tamat SD & 75 & 63.5 \\
& SMP & 2 & 1.69 \\
& SMA & 1 & 0.8 \\
& S1 & 1 & 0.8 \\
& Total & 118 & 100.0 \\
Jenis Pekerjaan & Petani & 62 & 52.5 \\
& Pedagang & 9 & 7.6 \\
& Buruh & 9 & 7.6 \\
& ASN & 3 & 2.5 \\
& Tidak Bekerja & 35 & 29.6 \\
& Total & 118 & 100.0 \\
\hline
\end{tabular}

Sumber : data primer diolah, 2019.

Analisis regresi linier berganda untuk menguji pengaruh antara dua atau lebih variabel independen dengan variabel dependen, adapun hasil perhitungan persamaan tersebut adalah :

Tabel 2. Hasil Uji Analisis Regresi Linier Berganda

\begin{tabular}{|c|c|c|c|c|c|c|}
\hline & Model & $\begin{array}{l}\text { Unstand. } \\
\text { B }\end{array}$ & $\begin{array}{l}\text { Coeff. } \\
\text { SE }\end{array}$ & $\begin{array}{c}\text { Stand. Coeff. } \\
\text { Beta }\end{array}$ & $\mathbf{t}$ & Sig. \\
\hline \multirow[t]{6}{*}{$\overline{1}$} & (Constant) & 9.918 & 2.736 & & 3.891 & .001 \\
\hline & Pengetahuan & .265 & .077 & .315 & 3.437 & .001 \\
\hline & Dukungan Masyarakat & .217 & .065 & .289 & 2.741 & .026 \\
\hline & Sikap & .189 & .083 & .098 & 1.867 & .043 \\
\hline & Akses & .191 & .066 & .068 & 1.708 & .045 \\
\hline & Pekerjaan & -.282 & .070 & 271 & 2.619 & .021 \\
\hline \multicolumn{7}{|c|}{ Dependent Variable : Perilaku Kunjungan Lansia } \\
\hline \multicolumn{7}{|c|}{$R^{2}=0,318 ;$ Adj $R^{2}=0,310 ; F_{\text {Test }}=2,684 ;$ Probability $=0,018$} \\
\hline
\end{tabular}

Sumber : data primer diolah, 2019. 
Berdasarkan hasil uji regresi linier berganda model 1 yang digunakan untuk menganalisis hipotesis ke-1, 2, 3, 4, dan 5 diketahui bahwa :

$$
Y=0,265 X_{1}+0,217 X_{2}+0,189 X_{3}+0,191 X_{4}+0,282 X_{5}+e
$$

Persamaan tersebut dapat dijelaskan sebagai berikut :

1. Nilai koefisien $X_{1}\left(\beta_{1}\right)$ bernilai positif sebesar 0,265 dan signifikan.

Hal ini sejalan dengan Notoatmodjo (2010), Purnama (2010), Sumiati (2013), Alhidayati (2014) dan Sunarti (2017) yang menyatakan bahwa pengetahuan merupakan faktor dominan yang terpenting dalam terbentuknya tindakan seseorang dan pengetahuan dapat diukur dengan melakukan wawancara. Perilaku yang didasari dengan pengetahuan dan kesadaran akan lebih bertahan lama daripada perilaku yang tidak didasari ilmu pengetahuan dan kesadaran.

2 Nilai koefisien $X_{2}\left(\beta_{2}\right)$ bernilai positif sebesar 0,217 dan signifikan.

Posyandu Lansia merupakan program Puskesmas yang melibatkan masyarakat sebagai kader kesehatan untuk membantu proses kegiatan di Posyandu Lansia. Jika kader yang terlibat pasif maka akan mempengaruhi kepasifan lansia untuk datang ke Posyandu Lansia. Hasil tersebut sesuai dengan teori yang dipaparkan Notoatmodjo (2010) bahwa dukungan sosial dari masyarakat sekitar akan mempengaruhi seseorang berperilaku terhadap kesehatan. Apabila perilaku tersebut tidak memperoleh dukungan dari masyarakat, maka seseorang akan merasa tidak nyaman sehingga tidak mempunyai motivasi untuk melaukan perilaku kesehatan.

3. Nilai koefisien $X_{3}\left(\beta_{3}\right)$ bernilai positif sebesar 0,189 dan signifikan.

Sikap merupakan reaksi atau respons seseorang yang masih tertutup terhadap suatu stimulus atau objek, yang sudah melibatkan faktor pendapat dan emosi yang bersangkutan. Temuan penelitian ini sejalan dengan pendapat Sunartyasih (2012) dan Handayani (2016) bahwa sikap lansia berhubungan dengan kehadiran lansia ke posyandu.

4. Nilai koefisien $\mathrm{X}_{4}\left(\beta_{4}\right)$ bernilai positif 0,191 dan signifikan.

Pada penelitian ini, menunjukkan bahwa akses yang ada di wilayah kerja Puskesmas Banjarsari mempengaruhi lansia datang ke Posyandu Lansia. Akses dari masing-masing rumah lansia ke tempat Posyandu Lansia mudah dijangkau, walaupun ada beberapa yang jauh tapi masih bersedia untuk datang ke Posyandu Lansia. Akses bukan menjadi penghalang lansia di wilayah kerja Banjarsari untuk datang ke Posyandu Lansia. Lansia sudah paham manfaat mengikuti kunjungan lansia bagi dirinya, sehingga memotivasi lansia untuk selalu datang ke Posyandu walaupun ada beberapa responden kurang setuju terkait akses menuju tempat pelayanan. Hasil penelitian ini tidak bisa sejalan dengan Erfandi (2013) dan Ningsih (2014) yang menyatakan bahwa akses adalah faktor kendala pelaksanaan posyandu.

5. Nilai koefisien $X_{5}\left(\beta_{5}\right)$ negatif 0,282 dan signifikan.

Walaupun para lansia bekerja namun tidak mempengaruhi motivasi lansia untuk datang ke Posyandu Lansia. Sebagian besar lansia di wilayah kerja Puskesmas Banjarsari masih bekerja, mayoritas petani, sebagian pensiunan dan pedagang. Pekerjaan tersebut tidak mempengaruhi lansia untuk berkunjung ke Posyandu Lansia, karena waktu pelaksanaan kegiatan Posyandu Lansia siang hari atau tidak bersamaan dengan waktu kerja lansia. Temuan penelitian ini mendukung Andini (2013), Henniwati (2008), dan Rosyid (2009) bahwa pekerjaan merupakan faktor yang mempengaruhi lansia untuk datang atau berkunjung ke Posyandu Lansia. 
Hasil uji regresi linier berganda dengan variabel moderasi (metode uji nilai selisih mutlak) model 2 yang digunakan untuk menganalis hipotesis ke-6, 7, 8, 9, dan 10 sebagaimana tabel berikut :

Tabel 3. Hasi Uji Moderated Regression Analysis

\begin{tabular}{|c|c|c|c|}
\hline Variabel & Koefisien & Signifikansi & $\mathbf{A R}^{2}$ \\
\hline Konstanta & 14,317 & 0,000 & \\
\hline Pengetahuan Terstandarisasi & 3,105 & 0,016 & 0,467 \\
\hline Dukungan Masyarakat Terstandarisasi & 2,311 & 0,023 & 0,389 \\
\hline Sikap Lansia Terstandarisasi & 1,941 & 0,034 & 0,399 \\
\hline Akses Terstandarisasi & 1,807 & 0,031 & 0,514 \\
\hline Pekerjaan Terstandarisasi & 2,891 & 0,021 & 0,491 \\
\hline Dukungan Keluarga Terstandarisasi & 2,681 & 0,013 & 0,552 \\
\hline $\begin{array}{l}\text { Selisih mutlak pengetahuan dan } \\
\text { dukungan keluarga terstandarisasi }\end{array}$ & 2,371 & 0,019 & 0,517 \\
\hline $\begin{array}{l}\text { Selisih mutlak dukungan masyarakat dan } \\
\text { dukungan keluarga terstandarisasi }\end{array}$ & 1,267 & 0,021 & 0,490 \\
\hline $\begin{array}{l}\text { Selisih mutlak sikap dan dukungan } \\
\text { keluarga terstandarisasi }\end{array}$ & 1,701 & 0,044 & 0,571 \\
\hline $\begin{array}{l}\text { Selisih mutlak akses dan dukungan } \\
\text { keluarga terstandarisasi }\end{array}$ & 1,861 & 0,038 & 0,620 \\
\hline $\begin{array}{l}\text { Selisih mutlak pekerjaan dan dukungan } \\
\text { keluarga terstandarisasi }\end{array}$ & 2,651 & 0,036 & 0,640 \\
\hline
\end{tabular}

Sumber : data primer diolah, 2019.

Pengetahuan yang dimiliki lansia tentang Posyandu Lansia akan mempengaruhi lansia untuk berkunjung ke Posyandu Lansia. Namun lansia akan lebih termotivasi untuk berkunjung ke Posyandu Lansia jika lansia mendapatkan dukungan keluarga untuk berkunjung dan berpartisipasi aktif. Hal tersebut ditunjukkan dari hasil analisis regresi moderasi bahwa dukungan keluarga mempunyai nilai positif dan signifikan dalam memoderasi pengetahuan dan perilaku kunjungan lansia ke Posyandu Lansia. Hal ini sejalan dengan penelitian Purnama (2010), Purnawati (2014) dan Iskandar \& Sunarti (2017).

Dukungan keluarga memoderasi dukungan masyarakat terhadap perilaku kunjungan lansia ke Posyandu Lansia dengan nilai positif dan signifikan. Dukungan keluarga mendorong minat atau kesediaan lansia mengikuti kegiatan Posyandu Lansia. Keluarga dapat menjadi motivator bagi lansia apabila selalu menyempatkan diri untuk mendampingi atau mengantar lansia ke Posyandu, mengingatkan lansia jika lupa jadwal posyandu dan sebisa mungkin berusaha membantu mengatasi segala permasalahan bersama lansia. (Erfandi, 2013).

Dukungan keluarga memoderasi sikap lansia terhadap perilaku kunjungan lansia ke Posyandu Lansia dengan nilai positif dan signifikan. Dengan adanya sikap yang baik tentang Posyandu Lansia disertai dukungan dari keluarganya akan mampu lebih meningkatkan motivasi lansia untuk berkunjung ke Posyandu Lansia. Menurut Friedman (2008) bahwa keluarga berfungsi sebagai sistem pendukung bagi anggotanya. Dukungan tersebut dapat dilakukan dengan cara meningkatkan dukungan emosional, penghargaan, instrumental, dan informatif yang diberikan oleh anggota keluarganya. 
Jarak yang dekat dan biaya yang murah saat melakukan kunjungan ke Posyandu Lansia membuat lansia bersemangat untuk berkunjung, apalagi jika saat melakukan kunjungan, lansia mendapat dukungan dari keluarga, maka akan semakin termotivasi. Hal tersebut diketahui dari hasil analisis uji moderasi dengan nilai positif dan signifikan yang berarti bahwa dukungan keluarga mampu memoderasi akses terhadap perilaku kunjungan lansia ke Posyandu Lansia, sebagaimana Erfandi (2013) dan Purnawati (2014).

Mayoritas lansia di Desa Gejagan bekerja sebagai petani. Walaupun demikian pekerjaan yang dilakukan oleh lansia tidak mempengaruhi motivasi untuk berkunjung ke Posyandu Lansia. Biasanya kegiatan Posyandu Lansia dilakukan di siang hari di mana kebanyakan lansia telah selesai bekerja. Selain itu, dukungan keluarga mampu memperkuat motivasi lansia untuk melakukan kunjungan ke Posyandu Lansia. Hal ini ditunjukkan dengan hasil uji analisis bahwa dukungan keluarga mampu memoderasi hubungan pekerjaan terhadap perilaku kunjungan lansia ke Posyandu Lansia dengan nilai positif dan signifikan, sejalan dengan Henniwati (2008) dan Rosyid (2009).

\section{KESIMPULAN}

Berdasarkan analisis dan pembahasan diketahui bahwa variabel yang paling mendominasi dalam mempengaruhi kunjungan lansia ke Posyandu Lansia adalah pengetahuan. Pengetahuan lansia mengenai manfaat, tujuan, dan jenis kegiatan yang akan dilakukan membuat lansia termotivasi untuk berkunjung ke Posyandu Lansia untuk mendapatkan pelayanan kesehatan yang diinginkan. Namun juga perlu diperhatikan faktor dukungan keluarga agar lebih mampu memotivasi lansia untuk berkunjung.

Berjalanannya program Posyandu Lansia di Desa Gejagan wilayah kerja Puskesmas Banjarsari sangat dipengaruhi pengetahuan lansia, sehingga jika lansia lebih memahami akan manfaat dari program ini akan membuat mereka termotivasi untuk berkunjung. Peningkatan pengetahuan lansia dapat diberikan melalui penyuluhan dari tenaga kesehatan untuk terjun langsung ke desa.

Selain itu, faktor dukungan masayarakat sangat menguatkan pelaksanaan kegiatan Posyandu Lansia. Dukungan masyarakat yang dimaksud yaitu dari perangkat desa dan kader aktif dalam menjalankan program ini. Tenaga medis dari Puskesmas juga hendaknya ikut aktif melakukan komunikasi terhadap perangkat dan kader kesehatan agar masyarakat lansia senantiasa tetap semangat untuk berkunjung ke Posyandu Lansia. Hal ini bisa menjadi satu-kesatuan antar tenaga kesehatan untuk lebih memproduktifkan kembali lansia di Desa Gejagan wilayah kerja Puskesmas Banjarsari.

Sikap lansia yang sangat positif terhadap pelaksanaan Posyandu Lansia menjadi potensi positif untuk meningkatkan program Posyandu Lansia agar lebih variatif dalam memberikan pelayanan dan memberdayakan lansia untuk lebih produktif.

\section{DAFTAR PUSTAKA}

Alhidayati. (2014). Faktor-Faktor yang Berhubungan Dengan Perilaku Kunjungan Lansia ke Posyandu Lansia di Kerja Puskesmas Kampar Kabupaten Kampar Tahun 2013. Jurnal Kesehatan Komunitas, 2(5). 
Andini., N., \& Susilowati. (2013). Faktor-Faktor Yang Mempengaruhi Penduduk Lanjut Usia Masih Bekerja. Piramida: Jurnal Kependudukan Dan Pengembangan Sumber Daya Manusia, IX(1): 44-49.

Anggraini, D. et al. (2015). Faktor Dominan Lansia Aktif Mengikuti Kegiatan Posyandu di Dusun Ngentak. Jurnal Ners dan Kebidanan Indonesia, 3(3), 150-155.

Arikunto, S. (2013). Prosedur Penelitian: Suatu Pendekatan Praktik. Penerbit Rineka Cipta, Jakarta.

Arwani, A. (2015). Pengaruh Sikap Mahasiswa Muslim Terhadap Minat Pada Bank Syariah. Jurnal Penelitian, 12(1).

As'ad, M. (2013). Psikologi Industri, Seri IImu Sumber Daya Manusia. Penerbit Liberty, Jakarta.

Dewi, S. R. (2014). Buku Ajar Keperawatan Gerontic. Penerbit Deepublish, Yogyakarta.

Departemen Kesehatan RI. (2010). Pedoman Pembinaan Kesehatan Lanjut Usia bagi Petugas.

Departemen Kesehatan RI. (2013). Riset Kesehatan Dasar.

Erfandi. (2013). Definisi Pengetahuan Serta Faktor Yang Mempengaruhinya. [Online] http://referensiparamedis.blogspot.com/2009/11/definisi-pengetahuan-serta-

faktor.html. [Diakses pada tanggal 26 Januari 2019].

Gestinarwati, A., Ilyas, H., \& Manurung, I. (2016). Hubungan dukungan Keluarga dengan Kunjungan Lansia Ke Posyandu. Jurnal Keperawatan, 12(2).

Ghozali, I. (2011). Aplikasi Analisis Multivariate dengan Program SPSS. Edisi X Semarang: Badan Penerbit Universitas Diponegoro.

Handayani, S. (2016). Efektifitas Terapi Religi terhadap Penurunan Tingkat Stress pada Lansia di Jakarta. Jurnal Ilmu Keperawatan.

Henniwati, (2008). Faktor-faktor Yang Mempengaruhi Pemanfaatan Pelayanan Posyandu Lanjut Usia Di Wilayah Kerja Puskesmas Sakti Kabupaten Aceh Timur. Tesis Pascasarjana Universitas Sumatera Utara

Hastono. (2009). Analisis Data Riskesdas 2007/2008. Jurnal Kesehatan Masyarakat Nasional. 4(2).

Ningsih, R., dkk. (2014). Faktor-faktor yang Mempengaruhi Minat Lansia Mengunjungi Posyandu Lansia. JOM PSIK, 1(2).

Notoatmodjo. (2010). IImu Perilaku Kesehatan. Jakarta: Rineka Cipta (2010). Promosi Kesehatan : Teori dan Aplikasi. Jakarta: Rineka Cipta. (2012). Promosi Kesehatan dan IImu Perilaku. Jakarta: Rineka Cipta

Purnama. (2010). Posyandu Lanisa. [Online] Terdapat di: http//:purnama.wordpress.com [Diakses tanggal 5 Juli 2019].

Purnawati, N., Irdawati., \& Yuniartika, W. (2014). Faktor-faktor yang Mempengaruhi Kunjungan Lansia Dalam Kegiatan Posyandu di Desa Plumbon Kecamatan Mojolaban Sukoharjo. [Online] Terdapat di: http://eprints.ums.ac.id/30723/. [Diakses tanggal 5 Juli 2019].

Puspitawati, H. (2012). Gender dan Keluarga: Konsep dan Realita di Indonesia. PT IPB Press. Bogor.

Rosyid, F., Uliyah, M., \& Hasanah, U, (2009). Faktor-faktor Yang Mempengaruhi Kunjungan Lansia Ke Posyandu Lansia Di RW VII Kelurahan Wonokusumo Kecamatan Semampir Surabaya. Journal From UM Surabaya. 5(1). 
Siyoto, S. (2015). Dasar Metodologi Penelitian. Cetakan 1, Yogyakarta: Literasi Media Publishing, Juni 2015.

Sulistyawati. (2012). Hubungan Antara Pekerjaan, Pendapatan, Pengetahuan Sikap Lansia Dengan Kunjungan Ke Posyandu Lansia. STRADA Jurnal IImiah Kesehatan, 1(2).

Sunartyasih, R., \& Linda, B. (2011). Hubungan Kendala Pelaksanaan Posbindu Dengan Kehadiran Lansia Di Posbindu RW.08 Kelurahan Palasari Kecamatan Cibiru Kota Bandung. Prosiding SNaPP2012: Sains, Teknologi dan Kesehatan.

Sugiyono, (2014). Metode Penelitian Kuantitatif dan Kualitatif dalam $R$ \& $D$. Bandung : Alfabeta

Soeweno, I. (2010). Pedoman Pelaksanaan Posyandu Lanjut Usia. Jakarta: Komnas Lansia. Umayana, HT., \& Cahyati, WH. (2015). Dukungan Keluarga dan Tokoh Masyarakat terhadap Keaktifan Penduduk ke Posbindu PTM. Jurnal Kesehatan Masyarakat, 11(2).

Utomo, ST. (2015). Hubungan Jenis Kelamin, Tingakt Pengetahuan, Dukungan Keluarga, Sikap lansia, Jarak, Pekerjaan dengan Kunjungan Lansia ke Posyandu Lansia. Tesis. FIK Universitas Muhammadiyah Purwokerto.

Wahyuni, DE., dkk. (2018). Persepsi Masyarakat terhadap Pelayanan Kesehatan Lansia di Posyandu Rindu kasih Sayang Nadila. Jurnal Kultur Demokrasi, 5(11). 